\title{
$[5]$
}

\section{Law and the Colonial State in India}

\author{
Bernard S. Cohn
}

In the second half of the eighteenth century, the East India Company had to create a state through which it could administer the rapidly expanding territories acquired by conquest or accession. The invention of such a state was without precedent in British constitutional history. The British colonies in North America and the Caribbean had from their inception forms of governance that were largely an extension of the basic political and legal institutions of Great Britain. The colonizing populations, even when drawn from dissident political and religious groups in Great Britain, still were thought of as English or British. The laws of these colonies were the laws of Great Britain.

The indigenous populations encountered in North America were quickly subjugated, relocated, or decimated, and even though there continued to be, from the colonial perspective, a "native" problem, it was a military and political one, requiring little in the way of legal or administrative innovation. In the Caribbean colonies, the indigenous population had all but been destroyed before British sovereignty was established, and the basic form of production through the plantations worked with enslaved labor was largely responsible for the maintenance of law and order. For the whites, the system of governance was much like that of the North American colonies. Only in Ireland, and to a lesser extent in Wales and Scotland, did the British face a colonial problem that 
required innovation. The solution in Ireland was the establishment of a Protestant landholding elite, with the virtual creation of plantations that a depressed Catholic peasantry provided with labor and rents.

\section{Creating Instrumentalities of Rule in Colonial India}

In all the British overseas Colonies, at least until 1776, there was little debate concerning the role of the Crown and Parliament and about the basic jural and legal institutions of rule. Debates in Great Britain and raised overseas by white colonists shared a common discourse, were based on assumptions about the nature of the state and society, and could be encompassed within the existing institutions of rule. The constitutional and legal issues presented by the emergence of the East India Company, a major territorial power in India after the Battle of Plassey in 1757, could not simply be analogized to existing colonial experience. A whole new set of issues, for which there was no precedent, presented themselves. The issues included questions about the nature of sovereignty in India. Generally speaking, most of the British who were concerned with India agreed that India had a state system-which by the middle of the eighteenth century was in decline and disarray but which had recognizable institutions and functions of a state. They also agreed that the peoples of India, unlike the Indians and slaves of the New World, had an ancient civilization and forms of local self-governance that were stable and deeply entrenched. The sheer size of the eastern territories and the huge numbers of people becoming subjects of the East India Company were seen as signs that some of the existing state forms should be adopted. The key resources of India were the products of labor, not natural ones, and they involved a well-developed market system. In Bengal and parts of South India, the East India Company had succeeded in acquiring control of the financial resources of the state in the form of taxes, through which they could acquire commodities for export and support the buildup of military power to defend their territories from Indian and French adversaries. The East India Company had over time acquired many of the attributes of a state, in European terms. It could wage war, make peace, raise taxes, and administer justice to its own employees and to increasing numbers of Indians who inhabited the territories in which the company was acting as the sovereign.

Debate centered on the question of whether a private company that 
was exercising state functions could do so on the basis of royal grants and charters. What responsibilities did such a private company have for the well-being and prosperity of its subjects? These and many subsidiary issues were to be argued and to become central political issues from 1760 to 1790 . By 1785, a dual principle of sovereignty had been established. The East India Company could administer its territories in its own name for the profit of its stockholders-but under regulations passed by Parliament, which would periodically review the adequacy of the company's system of governance in India. Although employees of the company owed allegiance to the British Crown, the natives of India-be they peasant or territorial rulers allied to the East India Company-did not. The company claimed its legitimacy in India from grants received or extracted from Indian rulers-for example, the grant Dewani of Bengal in 1765 , which made the company the responsible agent for assessment and collection of the revenues of Bengal. Concerns with constitutional questions, at home and in India, and with the construction of legitimacy that would enable the company to act as the state, were complex and difficult, but it was the pragmatics of building its administrative instrumentalities of rulership that were to engage those in India who were most directly concerned with the management of the company's territories.

In 1765 Clive wrote to his employers, the Court of Directors of the East India Company, informing them of the Mughal's grant of the Dewani of Bengal and claiming that the company "now became the Sovereigns of a rich and potent kingdom" and that they were not only the "collectors but the proprietors of the nawab's revenues." The directors' response to this news was less than enthusiastic, because they believed that Englishmen were "unfit to conduct the collection of revenues and to follow the subtle native through all his arts, to conceal the real value of his country, to perplex and elude the payments" (Srinivasachari 1962:184). Instead, the Directors envisioned their British servants supervising the collection and spending the revenues. There was a contradiction in what they were recommending, since the assessment and collection of land revenue was a complex and difficult job and in the hands of Indian specialists. If the British could not master the details of the revenue system, they would be dependent on those "subtle natives," who could "perplex" them at every turn. When in 1772 the British attempted to control their Indian subordinates by going into the "field," it was, as a modern historian has written, "a journey into the unknown. . . . At every step they came up against quasi feudal rights 
and obligations which defied any interpretation in familiar Western terms. The hieroglyphics of Persian estate accounts baffled them. . . . they could not easily master the language in which ancient and medieval texts relating to the laws of property were written; for tradition recorded only in memory and customs embedded in a variety of local usages wielded an authority equal to that of any written code" (Guha 1963:13).

In the British cultural system, the capacity to assess taxes was inextricably linked with law. The courts established and protected property rights and were the instrument for enforcing payment of the "King's share of the revenue." The British in India initially tried to find who "owned" the land, so that person could be made responsible for payment of revenue. In theory this seemed simple, but in practice, as Guha suggests, it was fraught with difficulties. Forms of knowledge that would enable the foreign rulers to frame regulations that would guarantee their obtaining what they thought was the just share of the surplus of agricultural production had to be acquired or created. After 1765, the British so badly managed the task of assessing and collecting land revenue that within five years they found that their actions had caused a horrendous famine, in which they estimated that a third of the population of Bengal had died. The famine left in its wake large tracts of land that were uncultivated and rapidly turning into wasteland. Hence they added to their perplexing efforts to create information a theoretical set of questions about how best to revive agricultural production in Bengal. Both the famine and the revenue policies of the British also led to a breakdown in law and order; roving gangs (dacoits) began to prey on a helpless peasantry and to disrupt trade.

\section{Hastings and the Redefinition of Traditional Forms of Authority and Rule}

Warren Hastings, who had a successful career in India as a commercial and diplomatic agent for the East India Company, was appointed in 1772, under a new parliamentary act, to the newly created position of governor-general and was instructed by the Court of Directors to place the governance of the Bengal territories on a stable footing. Hastings had to contend both with Indian complexities and British venality. Since 1757, appointments to the East India Company's service in Bengal were viewed as means of quickly attaining a fortune and, on return to England, the life of a successful country gentleman. He was also con- 
strained by a cumbersome form of government by a council of five, of which Hastings was in effect only first among equals.

The crucial actor in Hastings' plan for the better administration of Bengal was to be a British officer designated a "collector." The collector would have mixed executive and judicial powers in a defined area, a "district," whose boundaries followed preexisting Mughal revenue units termed circars, which were the constitutent units of the subas (provinces). Hastings had invented the emblematic figure of British imperialism who was to appear in Africa, Southeast Asia, and the Southwest Pacific, the man on the spot who knew "the natives," who was to represent the forces of "law and order."

The premise of Hastings' plan was the idea that during the seventeenth century the Mughals had an effective administrative structure, clearly not based on European principles, but nonetheless consonant with Indian theory and practice. He was also aware that during the previous fifty years in Bengal this system had all but crumbled under almost constant warfare, maladministration, the growth of local chieftains who had usurped imperial powers, and the privatization of public offices.

Having been a scholar at Westminster, Hastings brought to his task a good "classical" European education. Perhaps more important for the first fifteen years of his career, even though concerned with the East India Company's trading activities, he was stationed up-country near the court of the last of the effective nawabs of Bengal. There he acquired first-hand knowledge of how an Indian state functioned and could not totally share the prevalent British ideas that Indian rulers were despotic, corrupt, and extortionate. He believed that Indian knowledge and experience as embodied in the varied textual traditions of the Hindus and Muslims were revelant for developing British administrative institutions.

One of the first Persian works to be translated into English was the Ain-i-Akbari, by Abul Fazal, an "account of the mode of governing" under the most illustrious of the Mughal emperors, Akbar. The account is part prescriptive and part descriptive. It contains the rules and regulations by which the Mughal court governed, but it also offered detailed discussions of the properties of a good ruler, vivid accounts of the varieties of animals kept by the king, of how to lay out a camp, and of how jewels and other valuable items were classified. Also included were what the British thought of as more practical matters-the regulations of the judicial and executive departments, a survey of the lands, and a "rent 
roll" of the Mughal empire (Davies 1935:65-72; Feiling 1966:92-107; Marshall 1973; Blochmann 1965 (1873):v-ix).

Hastings encouraged a group of younger servants of the East India Company to study the "classical" languages of India-Sanskrit, Persian, and Arabic - as part of a scholarly and pragmatic project aimed at creating a body of knowledge that could be utilized in the effective control of Indian society. He was trying to help the British define what was "Indian" and to create a system of rule that would be congruent with what were thought to be indigenous institutions. Yet this system of rule was to be run by Englishmen and had to take into account British ideas of justice and the proper discipline, forms of deference, and demeanor that should mark the relations between rulers and ruled. According to one of his biographers, Hastings "had to modify and adapt the old to fit English ideas and standards. He had to produce a piece of machinery that English officials could operate and English opinion tolerate . . to graft Western notions and methods on to the main stem of Eastern Institutions" (Davies 1935:71).

However these tasks were to be accomplished, they had to pass the basic test applied by the owners of the East India Company-that the administration should produce a fixed and regular return in the form of revenue, which was to pay all the expenses of the colonial state as well as provide a profit for the investors. Throughout the history of the company and its successor, the Imperial Government of India, the best indicator of efficiency of the administration was its capacity to collect 100 percent of the assessed revenues. The British logic of administration rested on the capacity to classify actions into prefixed domains. If payment were made in cash or in kind by an agriculturalist to a superior, who appeared to have "rights" to the land, these payments were "rent," the receiver was a "landlord," and the payer was a "tenant." If the receiver of payments appeared to have a political function, maintained an army, provided protection, supported religious institutions, and displayed emblems of sovereignty, then the payments were taxes and the relationship constituted that of ruler and subject.

Hastings's "collector," in addition to his executive functions as a tax collector, was to preside over two courts. One, which dealt with revenue and civil litigation and followed Hastings's understandings of Mughal practice, was called the court of Dewani; the other, which dealt with internal order and criminal law, was called the Faujdari court. The substantive law to be administered in the Dewani court was Hindu law for Hindus and Muslim law for Muslims. In the Faujdari courts the law 
to administer was "Muslim" criminal law; in the Dewani courts the collector was to preside along with his Indian assistant, the Dewan. Sitting as a judge, the collector, was to establish the "facts" in the case based on testimony, usually in the form of depositions from witnesses, and the documentary evidence was placed before the court. The Dewan and a Hindu law officer (pandit) were to find the "law" that was applicable to the case. If the dispute to be adjudicated involved Muslims, the law that applied was to be determined by a Muslim law officer (maulavi). It was assumed that in both traditions there were legal texts that were in effect "codes," which were known and could be interpreted by legal specialists (usually referred to by the British as "law professors") who could provide authoritative decisions on the particular sections of the codes that applied. In stressing the importance of using "Indian law," as it could be objectified out of textual traditions, Hastings was rejecting the prevalent European theory that the Indian state was despotic.

\section{India as Lawless: The Despotic Model}

The word "despot" is derived from a Greek word applied to the head of a household, and from this point of view, to govern despotically was to rule "as a master over a slave." By extension, to the Greeks, despotism meant arbitrary rule, and Aristotle "made this extended meaning apply specifically to certain governments, in which legitimate royal power was intrinsically the same as master over slave" (Koebner 1951:276).

Alexander Dow, an East India Company servant, prefaced his translation of Ferishta's History of Hindostan, a history of the Muslim conquerors of India published in 1770-72 by writing:

The history now given to the public, presents us with a striking picture of the deplorable condition of a people subjected to arbitrary sway; and of the instability of empire itself, when it is founded neither on law, nor upon the opinions and attachments of mankind. . . . In a government like that of India, public spirit is never seen, and loyalty a thing unknown. The people permit themselves to be transferred from one tyrant to another, without murmuring; and individuals look with unconcern upon the miseries of others, if they are capable to screen themselves from the general misfortune. This, however, is a picture of Hindostan in bad times, and under the worst Kings. As arbitrary government can inflict the most sudden miseries, so, when in the hand of good men, it can administer the most expeditious relief to the subject. We accord- 
ingly find in this history, that the misfortunes of half an age of tyranny, are removed in a few years, under the mild administration of a virtuous prince. (Dow 1772, 1:xi)

Dow, and other English historians as well, stressed that the arbitrariness of the political order caused the salient characteristic of despotism to become the insecurity of property. The British believed that the Mughal emperor "owned" all the land of Hindustan and could distribute in the form of grants and jagirs to support the military nobility (Omrah or Amirs) throughout their lifetime or during his lifetime. They also believed that at the death of the emperor or a noble the land escheated to the Throne (but Dow recognized that in many cases such grants were renewed and given to a son of the holder). They understood that some of the Hindu kingdoms, such as those ruled by the Rajputs in western India, were in effect held in perpetuity by ruling families as subjects of the Mughals and was confirmed by payment of an annual tribute.

As with property, so also with honors. The Mughal emperor was thought to be the sole source of all honors in the state. These honors were not hereditary, as they usually were in England. They lasted only for the lifetime of the person to whom they were granted. The British believed that this prevented development of a status group in the polity that could check the arbitrary power of the emperor, as in European states. In the model of the Mughal empire created by the British, there were no primogeniture for inheriting the throne (masnad), and each succession of a Mughal was accompanied by a bloody war. "The power of disposing of the succession naturally belongs to a despot. During his life, his pleasure is the law. When he dies his authority ceases" (ibid., 2:xxxiii). The Mughal might nominate one of his sons, not necessarily the oldest, but the son must still fight for the throne. A "prince must die by clemency, or wade through the blood of his family to safety and Empire" (ibid., 3:xxxv).

Although it was recognized that there was "law" in India, that "law" was believed to be different from the European kind. Because the government was seen as based on "no other principle than the will of one [the Mughal]," the law was based upon his will, and hence, argued Orme (1805), there could not be "any absolute laws in its constitution; for these would often interfere with that will." Orme believed that in 1752 there were "no digests or codes of laws existing in Indostan: The Tartars who conquered this country could scarcely read or write; and when they found it impossible to convert them to Mohammedanism left 
the Hindus at liberty to follow their own religion. To both these peoples (the lords and slaves of this empire), custom and religion have given all the regulations at this time observed in Indostan. . . . Every province has fifty sects of Hindus; and every sect adheres to different observances" (ibid., p. 437). The British realized that there were a large number of judicial officials in India, and a regular system of courts, with the Mughal's darbar (court) at the top, and that redress was always open to the subjects of the emperor by going to his court to seek justice. But the courts found in the country were thought to be "extremely venal." Orme described the process of the administration of justice thus:

The plaintiff discovers himself by crying aloud, Justice! Justice! until attention is given to his importunate clamours. He is then ordered to be silent, and to advance before his judge; to whom, after having prostrated himself, and made his offering of a piece of money, he tells his story in the plainest manner, with great humility of voice and gesture, and without any of those oratorical embellishments which compose an art in freer nations.

The wealth, the consequence, the interest, or the address of the party, become now the only considerations. . . . The friends who can influence, intercede; and, excepting where the case is so manifestly proved as to brand the failure of redress with glaring infamy (a restraint which human nature is born to reverence) the value of the bribe ascertains the justice of the cause.

Still the forms of justice subsist; witnesses are heard; but brow-beaten and removed: proofs of writing produced; but deemed forgeries and rejected, until the way is cleared for a decision, which becomes totally or partially favourable, in proportion to the methods which have been used to render it such. . . .

The quickness of decisions which prevails in Indostan, as well as in all other despotic governments, ought no longer to be admired. As soon as the judge is ready, everything that is necessary is ready: there are no tedious briefs or cases, no various interpretations of an infinity of laws, no methodized forms, and no harangues to keep the parties longer in suspense.

Providence has, at particular seasons, blessed the miseries of these people with the presence of a righteous judge. The vast reverence and reputation which such have acquired, are but too melancholy a proof of the infrequency of such a character. (Ibid., pp. 443-446)

In summary, the model of the Mughal-Indian political system was absolute and arbitrary power, unchecked by any institution, social or political and resting in the person of the emperor, with property and honors 
derived solely from the will of the despotic ruler. There were no fixed rules of inheritance and, above all, no primogeniture; succession to the throne was based on an inevitable struggle among the sons of the emperor. Justice was dependent not on the rule of law but on the rule of men, who could be influenced by money, status, and connection in the exercise of their office of judge.

The idea that India had been ruled by "despots" was revalorized in the nineteenth and twentieth centuries as one of several ruling paradigms that formed the ideological infrastructure of British rule in India. In its cleaned-up version it was expressed thus: Indians are best ruled by a "strong hand," who could administer justice in a rough-and-ready fashion unfettered by rules and regulations. The courts, their procedures, their regulations, and the propensity of Indians to perjury and to the suborning of witnesses only served to delay justice and made the simple peasant folk of India the prey of the urban-based lawyers, merchants, and agitators. This would lead to the alienation of the "natural" loyalty the masses always felt for the strong, benevolent despot. As benevolent despots, the British were to appear in several forms-as "platonic guardians," as patriarchs habitually addressed by the simple folk as "ma-bap" (mother and father), as authoritarian rationalist utilitarians, and in times of crisis as the not-so-benevolent Old Testament avengers (Iyer 1960; Wurgaft 1983:17-53; Hutchins 1967:17-153).

\section{India as a Theocracy: Classical Models of the Indian State}

Simultaneously with the development of the despotic model, Hastings and some of his associates in Calcutta were elaborating a countermodel of India as a theocratic state. This model included established and highly detailed codes of conduct that had the power of law and had already been worked out in the ancient era (as far as Hindus were concerned) and since the time of the Prophet in the Sacred Law (for Muslims). For both Hindu and Muslim law there were extensive bodies of texts and commentaries and sophisticated legal specialists who were the maintainers, expositors, and interpreters of these legal traditions.

In 1772 and 1773 a parliamentary committee was investigating the affairs of the East India Company and trying to decide what institutions of governance were most appropriate for restoring law, order, and prosperity to the company's territories. In this context, influenced by the 
"India as despotic" theory, it was argued that because there was no law in India, British law and institutions should be introduced into the vacuum. On hearing these reports, Hastings lobbied influential members of the Court of Directors and Parliament to prevent this, arguing that British law was too technical, too complicated, and totally inappropriate for conditions in India. He declared that the "ancient constitution" of Bengal was very much intact (Gleig 1841, 1:273,401). Writing to the Lord Chief Justice in 1774, Hastings denied the validity of the idea that India was ruled by nothing more than "arbitrary wills, or uninstructed judgements, or their temporary rulers" and the notion that "written laws are totally unknown to the Hindoos, or original inhabitants of Hindostan" (ibid., p. 400). The Hindus, Hastings averred, "had been in possession of laws which continued unchanged, from remotest antiquity." These laws were known to the Brahmins ("professors of law," found all over India) and supported by "public endowments and benefactions." These professors received a "degree of personal respect amounting almost to idolatry" (ibid.). This attitude of reverence for the Brahmin specialists in law was so entrenched that it was left unmolested even by Muslim governments.

The logic of Hastings's model of Hindu law read as "an ancient constitution" required that it be made accessible to the British who now were sitting as judges in the civil courts and would have to pass judgment on disputes "concerning property, whether real or personal, all cases of inheritance, marriage and caste; all claims of debt, disputed accounts, contracts, partnerships and demands of rent" (Great Britain, House of Commons 1772-73, 4:348). Some way to authoritatively establish the content of Hindu law to be administered in the East India Company's district courts had to be found. To this end, Hastings persuaded "eleven of the most respectable pandits in Bengal" to compile from the Shastric literature on Hindu law a code that could be translated into English for the newly appointed judges to use. Because at the time there was no European in Calcutta who knew Sanskrit, the compilation by the pandits was translated first into Persian and then from Persian into English. As if this chain of translations is not tortuous enough, the Persian translation was done by a Bengali Muslim, who would discuss in Bengali with one of the pandits the passages being translated and then gloss them into Persian. The English translation from the Persian was by a young civil servant, H. B. Halhed, and published in London in 1776 as A Code of Gentoo Laws or Ordinations of the Pundits (R. Rocher 1983:51). In his preface, Halhed described how the work had been produced: 
The professors of the ordinances here collected still speak the original language in which they were composed, and which is entirely unknown to the bulk of the people, who have settled upon those professors several great endowments and benefactions in all parts of Hindostan, and pay them besides a degree of personal respect little short of idolatry, in return for the advantages supposed to be derived from their studies. A set of the most experienced of these lawyers was selected from every part of Bengal for the purpose of compiling the present work, which they picked out sentence by sentence from various originals in the Sanscript $[s i c]$ language, neither adding to, nor diminishing any part of the ancient text. The articles thus collected were next translated literally into Persian, under the inspection of one of their own body; and from that translation were rendered into English with an equal attention to the closeness and fidelity of the version. (Halhed 1776:x)

The original compilation in Sanskrit was termed vivadarnavasetu, "bridge across the sea of litigation," and was circulated in Persian, Sanskrit, and English version and used in the East India Company's courts until the early nineteenth century (Derrett 1968:240-241). The two leading scholars of the code disagree about its relationship to the legal traditions of eighteenth-century Bengal. Derrett (ibid., p. 240) argues that the topics covered-“Debt, Inheritance, Civil Procedure, Deposits, Sales of Strangers' Property, Partnership, Gift, Slavery, Master and Servant, Rent and Hire, Sale, Boundaries, Shares in Cultivation of Lands, Cities, and Towns and Fines for Damaging Crops, Defamation, Assault, Theft, Violence, Adultery, Duties of Women"-were topics Hastings believed would be useful in the district courts. He also asserts that the order in which the sections appear "does not correspond with anything known to the usual Shastric texts" (ibid., p. 241), that the pundits were working on a list of topics supplied by Hastings (ibid., p. 241).

In a recently published detailed study of Halhed's career, Rosane Rocher (1983:51) argues that the Sanskrit version of the code was a "traditional compilation of the Nibandha type, i.e. excerpts from a variety of authoritative sources, and extensive commentary." She attributes the difference between her interpretation and Derrett's to the fact that his was based on the English version of the code, which does not accurately reflect the Sanskrit original (ibid., p. 65, n. 20). The enduring significance of Halhed's translation has much less to do with the further development of the East India Company's legal system than with its role in establishing Indological Studies in Europe, where the work was read 
in English and in translation in French and German, for information about the "mysterious" Hindus.

In his preface to the translation of the Gentoo Code, Halhed makes it clear that his interests were not primarily legal, but concerned more with explicating Hindu thought, religion, and customs in relation to establishing a policy of toleration, on the part of the British toward the conquered Indians. Halhed held up the model of the Romans, "who not only allowed to their foreign subjects the free exercise of their own religion and the administration of their own civil jurisdiction, but sometimes, by a policy still more flattering, even naturalized parts of the mythology of the conquered, as were in any respect compatible with their own system" (Halhed 1776:ix). Halhed's reference to Roman imperial policy adumbrates the next phase of British efforts to find a basis for their legal system with respect to Hindu personal law in the work of Sir William Jones.

Sir William Jones (1746-1794), a classical scholar who studied Persian and Arabic at Oxford and qualified as a barrister, had by the time of his appointment to the Crown Court in Calcutta, in 1783, published a number of translations of Arabic and Persian works and written one of the first modern Persian grammars. In addition, he had an active political career and was a major intellectual figure of the time (Mukherjee 1968; Cannon 1964). Jones had long lobbied his political friends for an appointment as a judge in India, which he hoped would provide him with financial security and the opportunity to further his orientalist studies. He originally did not think he would learn Sanskrit because he was too old, but as he began his judicial career in India he found that Halhed's code was badly marred-"rather more curious than useful" (see Cannon 1970, 2:797). There were Persian translations of some Sanskrit legal texts, but Jones believed these were defective too. He was therefore at the mercy of "native" lawyers, as were the other British judges, and he determined to learn the rudiments of that "venerable and interesting language," Sanskrit, in order that the "stream of Hindu law remain pure" (ibid., pp. 666-680). By 1786, Jones felt his Sanskrit was good enough that he could decide between differing opinions of his pandits by reading the "original tracts" and pronouncing whose interpretation of the law was correct (ibid., p. 718).

Shortly after his arrival in India, Jones sent Edmund Burke, the leading critic of the administration of the East India Company in Bengal, his ideas for the "Best Practicable System of Judicature" (ibid., pp. 643644 , n. 1). British law, Jones wrote to Burke, could not become the law 
of India because that would be counter to the very nature of an established legal system. There was no doubt in Jones's mind that British law was superior to the law existing in India, but even "a system of liberty, forced upon a people invincibly attached to opposite habits, would in truth be a system of tyranny." The system of judicature "affecting the natives of Bengal" had to be based on the "Old Mogul constitution." The basis of the law to be administered in the company's court should be digests of "Hindu and Mahomedan laws" compiled by "Conogos [keepers of land records] and Maulavis and Pandits," whom Jones (and most of the British at the time) considered to be a combination of legal scholars and practicing lawyers. There should be attached to the East India Company's court "native interpreters of the respective laws," but the honesty and competence of these interpreters had to be guaranteed by careful selection and by pay adequate to place them above temptation. The British judges, however, had to be in a position to be able to "check upon the native interpreters." This was to be accomplished through the "learning and vigilance" of the British judges. "The laws of the natives must be preserved inviolate," and the decrees of the courts must be conformable to Hindu or Mahomedan law" (ibid., pp. 643-644).

If the system Jones hoped to see implemented was to succeed, it would require that several forms of knowledge become codified and public. The British judges and other officials would require access to what Jones and others believed at the time was "the Hindu and the Mahomedan law," locked up in the texts and the heads of pandits and maulavis. A fixed body of knowledge that could be objectified into Hindu and Muslim law had to be found. This body of knowledge could be specified, set into hierarchies of knowledge linearly ordered from the most "sacred" or compelling to the less powerful.

Jones and others believed there was historically in India a fixed body of laws, codes, that had been set down or established by "law givers" and that over time had become corrupted by accretions, interpretations, and commentaries. They also believed that this jungle of accretions and corruptions of the earlier pure codes was controlled in the present by the Indians the British thought of as the Indian lawyers. An Ur-text that would simultaneously establish the Hindu and Muslim law and free the British from depending on fallible and seemingly overly susceptible pundits and maulavis for interpretations and knowledge had to be found or reconstituted. The task also had to be accomplished somehow by using the knowledge that their Indian guides, the mistrusted pandits and maulavis, seemed to monopolize. Even before arriving in India, Jones seemed to distrust Indian scholars' interpretations of their own 
legal traditions, a distrust that grew in India. He wrote to the GovernorGeneral Cornwallis in $\mathbf{1 7 8 8}$ that he could not with "an easy conscience concur in a decision, merely on the written opinion of native lawyers, in any case, in which they could have the remotest interest in misleading the court" (ibid., p. 795). Jones wanted to provide the British courts in India, the Crown, and the East India Company with a sure basis on which to render decisions consonant with a true or pure version of Hindu law. Then the pandits, the Brahmins, and the Indian "lawyers" henceforth could not "deal out Hindoo law as they please, and make it at reasonable rates, when they cannot find it ready made" (ibid., p. 684).

What began as a kind of personal effort to correct what he saw as the villainy or venality of some of the law officers of the court was to grow within a few years of Jones's arrival in India into a much more ambitious project to compile a "complete digest of Hindu and Mussulman law" (ibid., p. 699). In proposing this to the Acting Governor General, Jones worried that if his plan were known to the officials in London he would be accused of "proposing to be made the Justinian of India" (ibid.). By 1787, Jones had formulated a plan for the administration of justice in India that he believed would be in accord with the Indians' own principles of jurisprudence. The goal was to develop "a complete check on the native interpreters of the several codes" (Jones to Rouse, in ibid., p. 720). Jones wanted a "complete digest of Hindu and Musliman Laws, on the great subjects of Contracts and Inheritances" (ibid., p. 721). He wanted to employ two pandits and two maulavis at 200 rupees a month, and two writers (one for Sanskrit and one for Arabic) at 100 rupees a month. The modus operandi would be that of Tribonian, compiler of the Justinian Code, and the digest would consist of only "original texts arranged in a scientific method" (ibid.). Jones then went on to describe the texts he wanted to abstract and translate:

I would begin with giving them a plan divided into Books, Chapters, and Sections; and would order them to collect the most approved texts under each head, with the names of the Authors, and their Works, and with the chapters and verses of them. When this compilation was fairly, and accurately transcribed, I would write the Translation on the opposite pages, and after all inspect the formation of a perfect index. The materials would be these; Six or Seven Law Books believed to be divine with a Commentary on each of nearly equal authority; these are analogous to our Littleton, and Coke. (Ibid., pp. 721-722)

In March 1788, Jones formally wrote to Cornwallis to request government support for this plan. He reiterated the argument that the compilation and its translation into English would establish a "standard of 
Justice" and that the English judges would have accessible to them the "principles" and "rules of law applicable to the cases before them" (ibid., 795). Thus Cornwallis hoped to become "the Justinian of India," and Jones by implication would become the Tribonian. The British government would give to the natives of India "security for the due administration of justice among them, similar to that which Justinian gave to his Greek and Roman subjects," Jones wrote to Cornwallis (ibid., p. 798). Cornwallis was quick to agree to support Jones's efforts to assemble the pandits, maulavis, and munshis to carry out his ambitious plans (ibid., pp. 801-806); Sinha (1972:626,660-661). From 1788 until his death in Calcutta in 1794, Jones continued to devote as much time as he could spare from his regular judicial duties to supervising the assembling and collating of the materials that were to become the Digest. At his death in 1794, the compilation in Sanskrit and Arabic texts was complete, and he had begun translating them into English (Tripathi 1978:349). By 1797 the English translation was completed by H. T. Colebrooke and published as The Digest of Hindu Law on Contracts and Successions in Calcutta in 1798.

The Court of Directors of the East India Company expressed their respect for Jones's achievements in India by commissioning a monument placed in St. Paul's Cathedral by the sculptor John Bacon (the Younger). Jones in the statue is depicted wearing a toga, with pen in hand and leaning on two volumes that "are understood to mean the Institutes of Menu" (Smyth 1826, 2:631).

Jones, and especially his successor, Colebrooke, established a European conception of the nature of Hindu law that was to influence the whole course of British and Indo-British thought and institutions dealing with the administration of justice down to the present. There was an inversion and contradiction in Jones's efforts to fix and translate what he believed to be the crucial aspects of Hindu law. Jones was trained in English common law, which although it embodied principles, legislation, ideas of natural law, and the concept of equity and justice was essentially seen as case law. Case law was a historically derived law based on the finding of precedent. It was flexible and above all subject to multiple interpretations by judges and lawyers. Jones and other jurisprudes of his time saw the English common law as responsive to historical change. Because the manners of a nation of people-or today we might say their culture-could change, legislation would be ineffective "unless it was congenial to the disposition, the habits, the religious prejudices, and approved immemorial usages of the people for whom it 
was enacted" (Jones 1798:75). But it appears that Jones believed that even though manners, habits, dispositions, and prejudices were not fixed or immutable, the Hindus of India had usages that were fixed from time immemorial. Unlike the British with their case law, in which a lawyer could trace changes both in manners and in customs as well as in the law, the Hindus therefore lived a timeless existence, which in turn meant that differences in interpretations offered by Pundits must have arisen from ignorance or venality.

Jones and the British believed that the original or earliest legal text was assumed to have the most authority. Jones's conception of Hindu law was that its authority was seen by Hindus to derive from its "sacredness" and its antiquity. The authoritativeness of Hindu law was compounded by the texts being written in Sanskrit, which as a language was unchanging, ancient in origin, and sacred. Colebrooke (1873, 2:465), translator of the Digest, believed that "the body of Indian law comprises a system of duties religious and civil." This being the case, the portions of the texts dealing with what the British thought of as ethical and religious matters-instructions for rituals, incantations, speculative philosophy, and even rules of evidence-all had to be excised to produce what the British thought of as the rules determining "contracts" and "succession." The object was to find and fix a Hindu civil law concerned with the topics that Jones, a Whig in political and legal philosophy, was centrally concerned with - those rights, public and private, that affected the ownership and transmission of property.

Jones, like Hastings, rejected the idea that India's civic constitution was despotic. He believed that in antiquity in India there had been "legislators" and "law givers," of whom Manu was "not the oldest only, but the holiest" (Jones 1798:76). What Manu and subsequent commentators had therefore created was "a spirit of sublime devotion, of benevolence to mankind, and of amiable tenderness to all sentient creatures ... . [that] pervades the whole work; the style of it has a certain austere majesty that sounds like the language of legislation and extorts a respectful awe" (ibid., pp. 88-89). Jones wanted to restore to India its laws, which pre-dated the Islamic invasions. To be content and productive under British rule, the 30 million black subjects of the East India Company, "whose well directed industry would add largely to the wealth of Britain" needed no more "than protection for their persons, and places of abode, justice in their temporal concerns, indulgence to their prejudices of their own religion, and the benefit of those laws, which they have been taught to believe sacred" (ibid., pp. 89-90). 


\section{Colebrooke and the Discourse on the Nature of Hindu Law}

Colebrooke, who completed the translation of Jones's Digest after his death in 1794, had been appointed to the East India Company service in 1782. His father was a banker who had an active role in the management of the company. Educated at home, Colebrooke had a good knowledge of classical languages and a special interest in mathematics. The latter interest led him in India to study Sanskrit, as he wanted to acquire knowledge of the "ancient algebra of the Hindus" (Colebrooke 1873, 1:53). In 1795 he was posted as a judge in Mirzapur, where he had access to the Hindu College in Banaras recently founded by the East India Company "to preserve and disseminate a knowledge of Hindoo law" and to "collect treatises on the Hindoo religion, laws, arts and sciences" (Narain 1959:171).

With access to this collection and to pandits in Banaras, Colebrook's interest shifted from mathematics to Hindu thought, culture, and law. He was a much better Sanskritist than Jones, and he developed a quite different conception of the nature and function of Hindu law. He also had a much firmer grasp on the nature of Shastric texts and their history. More than any Englishman, Colebrooke fixed an interpretation of variation in the legal texts that was to become standard in the British courts. "The Dharma-sastra or sacred code of law . . . is called smriti," Colebrooke wrote, "what was remembered, in contra distinction to sruti, what was heard." The Smriti or Dharma shastra, he wrote in a memorandum to Sir Thomas Strange, Chief Justice of Madras, is a form of knowledge concerned with "inculcating duty or the means of moral merit" (Colebrooke 1873, 1:666; Strange 1825). Colebrooke argued that Dharma satra had less to do with what Europeans thought of as substantive law, legal norms, and more to do with what was forensic law, which was concerned with the nature of pleadings in court or evaluation of evidence and the logic of legal argument.

Law, to Jones, was a set of prescriptive norms, the breach of which would be the cause for judicial redress. Such norms could best be sought, Colebrooke pointed out, in collections called Sanhitas, which Hindus attributed to holy sages or sacred personages. These collections were extensive in number. Colebrooke went on to explain that these ancient sages produced treatises on which subsequent Hindu lawyers or pandits commented; the whole, the original treatises and the numerous 
commentaries on them, formed the body of legal texts. In addition, a vast number of texts "were subject to the same rules of interpretation and collected in Mimamasa"-disquisitions on the proof and authority of precepts, which Indians "considered as a branch of philosophy, and is properly the logic of the law" (Colebrooke 1873, 1:95). Mimamasa was and is the method used to reconcile conflicting texts of equal authority by applying various rules for the interpretation of words, phrases, and sentences; it was also a style of argumentation (Derrett 1973:51-52).

While English jurisprudence of Jones's time sought certainty in the law, through either "rationality" or an ultimate appeal to ideas of natural law, Hindu jurisprudence sought flexibility through fixed means to interpret what had been revealed to man in terms of principles of right action and proper duties. A British lawyer schooled in case law was skilled in finding precedent in the case record and by analogy relating this precedent to a particular case. The Hindu lawyer, a logician and dialectician, sought reconciliation of conflicting interpretations through analysis of meanings and intentions. It must be remembered that Colebrooke, unlike Jones, was not trained in English law and did not have the knowledge of Roman law-aspects that marked Jones's intellectual approach to Hindu law. Colebrooke's solution to the problem of conflicting interpretations was to suggest that there were regional variations or differences that led to the "construing of the same text variously" (Colebrooke 1873, 1:95). Ultimately, Colebrooke attributed the variations to historical and cultural differences in India, "for the whole Hindu people comprise diverse tongues; and the manners and opinions prevalent among them differ no less than their language" (ibid., p. 96).

Colebrooke organized the differences conceptually, in what he termed "schools" of Hindu law. Ludo Rocher (1972:168) has argued that the invention of the concept of schools of Hindu law "engrafted upon Hindu law an element which was foreign to it." The source of Colebrooke's conceptions, Rocher argues, was based on several misconstructions. Colebrooke viewed the commentaries on Hindu legal texts as the work of "lawyers, juriscouncils and lawgivers" reflecting "the actual law of the land" (ibid., p. 170). This was analogous to early modern English jurisprudes who sought English law in the varied customs of different parts of Great Britain. The second misunderstanding was the analogy made between Hindu law and Muslim law. The British were familiar with Muslim law, with its relatively clear distinctions between Sunni and Shia, with the Sunni having four variations: Hanafi, Shafai, Maliki, 
and Hanbali. Colebrooke seems to have analogized this to Hindu law, yielding a symmetrical set for Hindu law to match what were thought of as the schools of Muslim law:
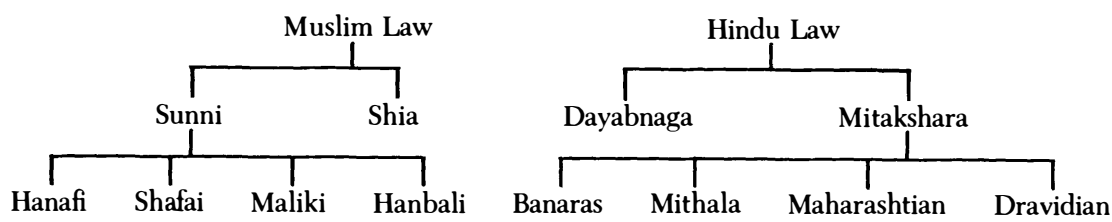

Colebrooke believed that the text, compiled by Jagannatha under Jones's direction was defective because it did not order the "discordant opinions maintained by the lawyers of the several schools" of Hindu law (Colebrooke 1873, 2:479). In Colebrooke's view each school had fixed "doctrines," and English judges therefore needed access to "those authentic works in which the entire doctrine of each school, with the reasons and arguments by which it is supported, may be seen at one view and in a connected shape" (ibid., p. 978).

If those Indian scholars who were cooperating with the British could not compile the texts that demonstrated the stability and completeness required for the administration of Hindu law in British courts, European methods must be used to achieve these ends. Colebrooke's solution was to supply a chronology to establish the authenticity the texts seemed to lack. The search for the oldest text was supposed to yield the most authoritative and authentic statement. If one could establish a chronological sequence of texts and trace them to a single original source, the tremendous variation added by subsequent commentators could also be controlled. Indian texts did have authors. Frequently one author cited another, and some texts appeared to contain bare facts about the relative chronological ordering of authors and commentators, but information on the history and age of authors was "very imperfect, as must ever be the case in regard to the biography of Hindu authors" (ibid., 2:487). An agreed-on authoritative, fixed chronology was not established. Gradually over the next forty years, after Jones announced his intention to provide Hindus with their own laws through the mediation of English judges assisted by court-appointed Pandits, a peculiar kind of case law came into being. At base there might be reference to a text of a particular author who was thought to represent the norm of a particular regional school, but it is the chain of interpretations of precedents by the English judges that became enshrined as Hindu law in such collections as Thomas Strange's Elements of Hindu Law. 
After the reform of the judicial system in 1864, which abolished the Hindu and Muslim law officers of the various courts of India, and after the establishment of provincial High Courts, publication of authoritative decisions in English had completely transformed "Hindu law" into a form of English case law. Today when one picks up a book on Hindu law, one is confronted with a forest of citations referring to previous judges' decisions-as in all Anglo-Saxon-derived legal systems-and it is left to the skills of the judges and lawyers, based on their time-honored abilities to find precedent, to make the law. What had started with Warren Hastings and Sir William Jones as a search for the "Ancient Indian Constitution" ended up with what they had so much wanted to avoidwith English law as the law of India.

\section{REFERENCES}

Blochmann, H. 1965. The Aini Akbari [Translation]. New Delhi. First published in Calcutta, 1865.

Cannon, Garland. 1964. Oriental Jones. Bombay.

. 1970. The Letters of Sir William Jones. 2 vols. Oxford.

Colebrooke, H. T. 1873. Miscellaneous Essays by H. T. Colebrooke. 3 vols. London. Davies, A. M. 1935. Strange Destiny: A Biography of Warren Hastings. New York.

Derrett, J. D. M. 1968. Religion, Law, and the State. New York. 1973. Dharmashastra and Juridical Literature. Wiesbaden.

Dow, Alexander. 1772. The History of Hindustan. 3 vols. London.

Feiling, Keith. 1966. Warren Hastings. London.

Gleig, G. R. 1841. Memoirs of the Life of Warren Hastings, First Governor-General of Bengal. 3 vols. London.

Great Britain, House of Commons. 1772-73. Reports from Committee on East Indies to Great Britain's House of Commons. Vol. 4. London. Reprinted 1804.

Guha, Ranajit. 1963. A Rule of Property for Bengal. Paris.

Halhed, H. B. 1776. A Code of Gentoo Laws; or, Ordinations of the Pundits. London.

Hutchins, Francis G. 1967. The Illusion of Permanence. Princeton.

Iyer, Raghaven. 1960. "Utilitarianism and All That." In Ragahavan Iyer, ed., South Asian Affairs 1, St. Anthony's Papers 8. London.

Jones, Sir William. 1798. "Preface." The Digest of Hindu Law on Contracts and Successions. Calcutta.

Koebner, R. 1951. "Despots and Despotism: Vicissitudes of a Political Term." Journal of the Warburg and Courtald Institutes 14:276.

Marshall, Peter. 1973. "Warren Hastings as Scholar and Patron." In Ann Whiterman et al., eds., Statesmen, Scholars, and Merchants, pp. 242-262. Oxford.

Mukherjee, S. N. 1968. Sir William Jones: A Study in Eighteenth-Century British Attitudes to India. Cambridge, Eng. 
Narain, V. A. 1959. Jonathan Duncan and Varanasi. Calcutta.

Orme, Robert. 1805 (1792). "General Idea of the Government and People of Indostan." In Historical Fragments of the Mogul Empire. London.

Rocher, Ludo. 1972. "Schools of Hindu Law." In J. Ensink and P. Gaeffke, India Maior: Congratulatory Volume Presented to J. Gonda, pp. 167-176. Leiden.

Rocher, Rosane. 1983. Orientalism, Poetry, and the Millennium. Delhi.

Sinha, Raghuber, ed. 1972. Fort William-India House Correspondence, vol. 10. Delhi.

Smyth, George L. 1839. The Monuments and Gennii of St. Paul's Cathedral and of Westminster Abbey. London.

Srinivasachari, C. S., ed. 1962. Fort William-India House Correspondence, vol. 4. Delhi.

Strange, Thomas. 1825. Elements of Hindu Law, vol. 1. Madras.

Tripathi, Amales, ed. 1978. Fort William-India-India House Correspondence. Delhi.

Wurgaft, Lewis D. 1983. The Imperial Imagination. Middletown, Conn. 